\title{
Social Exchange Relationship and Employee Attitudes toward Newly Introduced Information System
}

\author{
Paul Chou \\ Business Administration Department, Minghsin University of Science \& \\ Technology, Xinfeng Shiang, Hsinchu County, Taiwan
}

doi: 10.19044/esj.2016.v12n25p163 URL:http://dx.doi.org/10.19044/esj.2016.v12n25p163

\begin{abstract}
Almost all organizations in the world are under pressure to adopt new information systems in order to survive in competitive markets. Thus, improving our understanding of the inner working mechanism associated with adoption of new information systems has become increasingly important for researchers and practitioners alike. Although Davis' technology acceptance model is the most widely applied theory, very little effort has been devoted to understanding the determinants of new system acceptance and usage beyond Davis' model. In view of such, the main aim of this study is to investigate the driving force behind acceptance of and intent to use new information systems from the perspective of social exchange relationship. Results obtained confirm that perceived organizational support and leader-member exchange exert their influences via affective commitment to organization on attitude towards newly introduced information system. Practical implications, contributions and limitations of this study are discussed with suggestions for future research proposed.
\end{abstract}

Keywords: Social exchange relationship; affective commitment to organization; attitude towards new information systems

\section{Introduction}

Almost all organizations in the world are under pressure to adopt new information systems (IS) in order to survive in competitive markets. Current literature on IS has highlighted the existence of competition pressure on organizations and sought to provide guidance on the actions management should take to harness the effectiveness of information systems in order to secure a competitive position of a firm within its environment (Hammer and Champy, 1993). Specifically, Enterprise Resourcing Planning (ERP) systems have been introduced by many organizations in order to improve workflow and increase the efficiency of shared services and single database operations 
with streamlined processing, reporting, and access across operating units for the last two decades (Jacobson, Shepherd, D'Aquila, and Carter, 2007; Momoh, Roy and Shehab, 2010).

Indeed, successful investment in IS can lead to enhanced productivity, while failed systems can lead to undesirable consequences such as financial losses and dissatisfaction among employees (Venkatesh, 2000). Hence, successful adoption of newly introduced IS has become an important management task. Indeed, as Venkatesh (2000) noted, information technology acceptance and use is a critical issue that has received much attention for decades. Thus, understanding user acceptance, adoption, and usage of new IS is a high priority for both researchers and practitioners. With respect to theories of new technology adoption and acceptance, the technology acceptance model (TAM) is the most widely applied (Venkatesh, 2000).

Conceptually, the TAM suggests that perceived usefulness and perceived ease of use are beliefs about a new technology that influence an individual's attitude toward and use of that technology (Davis, Bagozzi and Warshaw, 1989). In essence, they are presumed to mediate the relationship between external variables and attitude (Davis et al., 1989). Moreover, there are some extended models developed by other researchers (e.g., DeLone and McLean, 1992,2003; Wixom \& Todd, 2005; Chen, Rungruengsamrit, Rajkumar, \& Yen, 2013).

Although there is a large body of research on IS supporting the impact of perceived ease of use, perceived usefulness, system quality, information system, service quality, user satisfaction, system satisfaction and information satisfaction on initial user acceptance and sustained usage of new systems from the perspective of TAM and other extended models, very little effort has been devoted to understanding the determinants of IS acceptance and use from the perspective of social fabric (Venkatesh, 2000). Doubtlessly, those aforementioned Models are valuable in understanding the driving force behind individuals' acceptance and use of new IS. However, to investigate from other perspectives matter as well. To make up for such deficiency, this study examines the antecedents of intent to use newly introduced IS from the perspective of social exchange relationships.

Further, in many cases, the reason for new IS implementation failure is a lack of change management (Ziemba and Obłak, 2015). In essence, adopting newly introducing information systems within an organization is a form of organizational change (Hornstein, 2015); and the process involved is essentially stressful because organizational change creates fear, uncertainty and doubt (Jaskyte, 2003; Vakola \& Nikolaou, 2005). Therefore, the premise of successful adoption of new information systems is to gain employees' positive attitude (i.e., acceptance and support) toward this change (Fedor, Caldwell, \& Herold, 2006; Miller, Johnson, \& Grau, 1994) since the attitude 
held by implementers, towards new IS is perceived as having some influence on the readiness to adopt new IS (Mulwa and kyalo, 2013) and attitude toward new IS means behavioral intention to use new IS (Chen, Rungruengsamrit, Rajkumar, \& Yen, 2013).

In addition, as Avgerou (2001) noted, pragmatic concerns about the social effects on usage of new technologies has recently become a highly visible part of IS research. Further, according to Cropanzano and Mitchell (2005), the aspect of SET that has garnered by far the most research attention has been the notion of social exchange relationships. Thus, this study aims at investigating the driving force behind acceptance and use of newly introduced IS from the perspective of social exchange relationship by examining the effects of POS and LMX on employees' attitude towards new IS.

\section{Literature Review}

\section{Social Exchange relationship at Workplace}

In essence, social exchange theory (SET) is among the most influential conceptual paradigms for understanding workplace behavior (Cropanzano and Mitchell, 2005). For decades, the concept of social exchange (Blau, 1964) has been used by organizational researchers to explain the motivational basis behind employee behaviors and the formation of positive employee attitudes. Social exchange theorists have alluded to employment as the trade of effort and loyalty for tangible and socio-emotional benefits (Blau, 1964). Specifically, one of the basic tenets of the social exchange theory is that relationships evolve over time into trusting, loyal, and mutual commitment and, to do so, rules and/or norms of exchange, which serve as the "guidelines" of exchange processes, must be obeyed by exchanging parties (Cropanzano and Mitchell, 2005).

Conceptually, according to the social exchange theory, employees perceiving that the firm is committed to them will feel obligated to reciprocate the firm's support orientation with voluntary contributions that benefit the firm (Organ, 1990). In other words, when one party treats another well, the reciprocity norm obliges the return of favorable treatment (Gouldner, 1960). Further, building on the norm of reciprocity (Gouldner, 1960), it is suggested that employees who perceive a high level of organizational support are more likely to feel an obligation to "repay" the organization in terms of affective commitment and work-related behavior (Eisenberger et al., 1986). That is, employees seek a balance in their exchange relationships with organizations and supervisors by having attitudes and behaviors that commensurate with the degree of employer commitment to them as individuals (Wayne et al., 1997).

According to Wayne et al. (1997), two types of social exchange have been studied in recent years. They are (1) exchanges between an employee and the employing organization termed as perceived organizational support (POS; 
Eisenberger et al., 1986) and (2) exchanges between an employee and his/her supervisor referred to as leader-member exchange (LMX; Graen and Scandura, 1987). Following their assertion, this study includes POS and LMX as main dimensions of social exchange relationship.

In summary, this study reasons that high-quality social exchange relationships can engender beneficial consequence for the organization (Cropanzano and Mitchell (2005). Accordingly, this study hypothesizes employees who perceive a high level of organizational support or have a highquality exchange with their supervisor will feel a sense of indebtedness and reciprocate the exchange partner (Wayne et al., 2002) by demonstrating affective commitment and supportive attitudes towards use new information systems.

\section{Perceived Organizational Support and attitude towards new Information system}

POS refers to employees' global beliefs that the firm cares about them personally and values their contributions to the organization (Eisenberger et al., 1990; Eisenberger et al., 1986). According to the organizational support theory (Eisenberger et al., 1986), employees who perceive organizational support will feel obligated to reciprocate the firm's supportive orientation with voluntary contributions that benefit the firm (Organ, 1990). Moreover, the theory asserts that workers act in accord with the norm of reciprocity by trading their effort and dedication to their organization for repaying organizational support (Eisenberger et al., 1990; Eisenberger et al., 1986). In other words, employees in a positive reciprocal relationship with their organizations should be more likely to contribute consistently to organizational welfare (Dyne, Graham and Dienesch, 1994).

Further, according to the norm of reciprocity and the social exchange theory (Blau, 1964), employees increase their efforts carried out on behalf of the organization to the degree that the organization is perceived to be willing and able to reciprocate with desirable discretionary and socio-emotional resources. Specifically, once employees have perceived organizational support, they tend to develop a generalized felt obligation to care about the organization's welfare and help the organization achieve its objectives (in this study, successful implementation of a new IS) (Aselage and Eisenberger, 2003; Eisenberger et al., 2001; Lind, Tyler and Huo, 1997; Wayne, Shore and Liden,1997; Wayne, Shore, Bommer and Tetrick, 2002) by demonstrating their positive attitudes(e.g., behavioral intent to support organizational change) towards organizational change (Fedor, et al., 2006).

On the other hand, POS would also be valued as assurance that help will be available from the organization when needed to carry out one's job effectively and to deal with stressful situations (Stinglhamber and 
Vandenberghe, 2003). That is, once organizational support is perceived by employees as a major resource upon which they can rely during organizational change, the perceived availability of support is likely to fortify their determination to attain their goals (Klein and Kim, 1998). In addition, as Blau (1964) argued, social exchange tends to engender feelings of personal obligations, gratitude, and trust. In other word, POS is associated with a trust that the organization will fulfill its exchange obligations (Organ and Konovsky, 1989; Settoon, Bennett and Liden, 1996; Wayne et al., 1997). That is, employees who trust their organizations are likely to have a positive perception toward the outcomes of the newly introduced IS and, further, tend to demonstrate positive attitude towards new IS.

In summary, this study assumes that employees who perceive organizational support, because of felt obligation and trust, tend not only to interpret the organization's gains and losses as their own, but also to perceive the outcomes of adopting new IS positively and, consequently, reciprocate in terms of attitudes and behaviors that benefit the organization (Wayne et al., 2002; Wayne et al., 1997). Accordingly, Hypothesis 1 is stated as follows.

H1: There is a positive relationship between POS and attitude towards new IS.

\section{Leader-Member Exchange and attitude towards new IS}

Leader-member exchange (LMX), originally termed vertical dyad linkage (Dansereau, Graen \& Haga, 1975), refers to the exchanges between a leader and his/her subordinates. The basic principle of leader-member exchange is that leaders develop different exchange relationships with their subordinates and that the quality of these relationships affects both leader and follower's attitudes and behaviors (Gerstner \& Day, 1997; Sparrowe and Liden, 1997). Drawing from social exchange theory, in order to explain the development of dynamic relationships and the linkages between leadership processes and outcomes (Ilies, Nahrgang and Morgeson, 2007), the LMX theory suggests that leaders influence their subordinates by developing social exchange relationships (Erdogan, Liden and Kraimer, 2006).

With LMX relationships rooted in a social exchange, there is a felt obligation on the part of subordinates to reciprocate high-quality relationships (Blau, 1964; Gouldner, 1960). In that case, one way in which subordinates can reciprocate these high-quality relationships is by performing their roles as required by their supervisor (i.e., engage in use of new information systems). In addition, leader-member exchange asserts that high-quality LMX relationships that are characterized by high level of trust. A handful studies suggest that trust is beneficial because it facilitates the effects of other determinants on desired outcomes (Dirks and Ferrin, 2001). In other words, trust provides the conditions under which more positive attitudes and perceptions are likely to occur (Dirks and Ferrin, 2001). 
Logically, in that case, employees who trust their supervisors are likely to have a positive perception toward the outcomes of the newly introduced information systems and, further, tend to demonstrate positive attitude towards new Information system. Hence, this study hypothesizes that employees who perceive high-quality LMX relationships tend to generate positive attitude towards new Information system. Accordingly, Hypothesis 2 is stated as follows.

H2: There is a positive relationship between LMX and attitude towards new IS.

\section{Mediating Role of Affective commitment}

Affective commitment to organization (ACO) is defined as an individual's identification with, involvement in, and emotional attachment to an organization, making the company's goals their own (Allen and Meyer, 1990; Meyer and Allen, 1991, 1997). Affective commitment has been the focus of ongoing research attention. There is considerable affirmative evidence in the literature to support that having committed employees tends to be positive for organizations (Fedor, Caldwell and Herold, 2006). For example, Individuals who are highly committed to their organization have less intention to leave; have a strong desire to contribute significantly to the growth of the organization; are less absent; more productive; make significant efforts in favor of their organization; and they have a strong desire to remain members of the organization (Bouarif, 2015).

For decades, there have been efforts to more fully understand commitment's antecedents as well as its consequences (Meyer, Stanley, Herscovitch, \& Topolnytsk, 2002). Indeed, affective commitment and job attitude is nowadays considered one of the most important and controversial elements in human resource management, and employee commitment is linked mostly to job attitudes (Judge and Kammeyer-Mueller, 2012). Thus, in this study, affective commitment is hypothesized to play a role of mediator between LMX, POS (antecedents, in this case) and attitude towards new IS (consequence, in this case).

\section{Perceived Organizational Support and Affective Commitment to Organization}

The concept of POS is rooted in the social exchange approach that describes the exchange of both parties with non-binding obligation (Arefin and Raquib, 2015). As noted above, POS meets the employees' socioemotional needs including approval, affiliation and self-esteem (Eisenberger et al., 1990) by providing resources to assist with managing demands of job (Eisenberger et al., 1986). Once employees feel the commitment of the organization, the employees are likely to have the same belief demonstrating 
their affective commitment toward organizations. In that case, POS would increase employees' ACO. In short, employees who perceive a high level of organizational support are more likely to feel an obligation to "repay" the organization by expressing stronger feelings of affiliation and loyalty to their organizations (Eisenberger et al., 1986; Loi et al., 2006; Malatesta, 1995).

Empirically, the positive relationship of organizational commitment with POS has been confirmed in studies conducted in the United States (e.g., Eisnberger et al., 1990; Settoon, Bennett and Liden, 1996; Eisenberger et al., 2001; Masterson et al., 2000; Rhoades \& Eisenberger, 2002; Rhoades, Eisenberger and Armeli, 2001; Wayne et al., 2002; Wayne, Shore and Liden, 1997), and outside the United States (e.g., Loi, Hang-Yue and Foley, 2006; Meyer et al., 2002). In addition, POS was found partially mediated the effect of favorable intrinsically satisfying job conditions on organizational affective commitment and fully mediated the effect of favorable extrinsically satisfying job conditions on organizational affective commitment (Stinglhamber and Vandenberghe, 2003). Accordingly, it is plausible to assume that there is a positive relationship between perceived organizational support and affective commitment to an organization.

\section{Leader-Member Exchange and Affective Commitment to Organization}

According to the concept of personification of organization (Levinson, 1965), actions by agents of the organization, such as supervisors, are often viewed as indications of the organization's intent rather than solely as actions of a particular individual. In this regard, subordinates would view favorable treatment as indicative of the organization's benevolent orientation toward them (Rhoades, Eisenberger and Armeli, 2001). Hence, employees who perceive high-quality exchange relationships with their supervisors are more likely to express stronger feelings of affiliation and loyalty to their organizations because of POS (Eisenberger et al., 1986; Loi et al., 2006; Malatesta, 1995).

Moreover, it is suggested that subordinates in high-quality LMX relationships will experience higher levels of job satisfaction because they receive preferential treatment as compared with their counterparts in lowquality LMX relationships (Lapierre and Hackett, 2007; Schriesheim, Castro, Zhou and Yammarino, 2001). In addition, several studies have reported a relationship between job satisfaction and ACO (Glisson and Durick, 1988; Iverson, 1996; Yousef, 2000).

Specifically, with respect to the relationship between LMX and ACO, high-quality LMX was empirically found to be positively associated with ACO (Eisenberger et al., 2010; Settoon et al., 1996; Wayne et al., 1997). Therefore, it is plausible to expect a positive relationship between leadermember exchange and affective commitment to organization. 


\section{Affective Commitment to Organization and attitude towards new Information system}

Conceptually, organizational commitment involves manifesting strong desire to remain a member of the organization and entails a high level of identification with the goals of the organization and the values it stands for (Allen and Meyer, 1990). In other words, with affective commitment, employees identify with the mission and goals of the organization (Witt, Kacmar, and Andrews, 2001). Hence, employees with strong organizational commitment are prone to be willing and committed to make extra effort towards realizing their organization's goals and manifesting these values. Further, Employees who commit to work toward the attainment of a goal (successful adoption of new IS in this case) can persist in spite of difficult challenges that might arise (Meyer and Herscovitch, 2001).

Specifically, it is suggested that individuals with high ACO would strongly identify with the vision of the organization and the goals/values of change initiatives (Dvir, Kass and Shamir, 2004). Thus, employees with a strong ACO are likely to value the course of action that is necessary for successful organizational change (in this study, adopting a new IS) and are therefore willing to do whatever is required to achieve the target of that action (Meyer, Srinivas, Lai, and Topolnytsky, 2007). In other words, those who affectively identify with the company and perceive the company's goals (in this study, successful implementation of a new IS) as their own (Fedor et al., 2006) are willing to do more than is required of them during organizational change (Vakola \& Nikolaou, 2005), even if it involves some personal sacrifice (Meyer and Herscovitch, 2001; Meyer, et al., 2007).

Prior studies evidenced empirically that ACO plays a vital role in employees' acceptance of change initiatives (Yousef, 2000; Iverson, 1996). For instance, Yousef's (2000) findings reveal a positive relationship between affective commitment and behavioral tendency attitudes toward organizational change. In particular, according to Iverson (1996), ACO can predict behavioral intention. As mentioned above, adopting newly introducing information systems within an organization is a form of organizational change. In this regard, it is reasonable to expect a positive relationship between ACO and attitude towards new IS.

In summary, according to all the inferences discussed above and after incorporating the simple bivariate associations into the initial hypotheses, Hypotheses 3 and 4 are stated as follows.

H3: ACO mediates the relationship between POS and attitude towards new IS.

H4: ACO mediates the relationship between LMX and attitude towards new IS. 


\section{Methods}

\section{Participants}

Invitations for participation were sent to three companies located at Hsinchu County, Taiwan which are undergoing ERP project less than 8 months. Procedure-wise, a total of 600 questionnaires with a cover letter explaining the purpose of the survey were sent to the head of the Human Resource Department of the three surveyed companies along with a return envelope for each participant to ensure that participants could send back the completed questionnaire on their own. A total of 350 questionnaires were returned (58\% response rate), with 334 valid questionnaires after screening $(56 \%)$.

Descriptive statistics for the valid respondents are presented in Table 1.

TABLE 1. Descriptive Profile of Respondents

\begin{tabular}{ccc}
\hline Gender & Male & $63 \%$ \\
& Female & $37 \%$ \\
\hline Job Rank & Managerial position & $17 \%$ \\
& Non- managerial position & $83 \%$ \\
\hline Age(years) & $<30$ & $30 \%$ \\
& $31-40$ & $44 \%$ \\
& $41-50$ & $21 \%$ \\
& $>50$ & $5 \%$ \\
\hline Seniority(years) & $>15$ & $47 \%$ \\
& $11-15$ & $23 \%$ \\
& $5-10$ & $12 \%$ \\
& $<5$ years & $18 \%$ \\
\hline Education Level & Master & $18 \%$ \\
& University Degree & $48 \%$ \\
& Diploma & $17 \%$ \\
& High School & $17 \%$ \\
\hline Annual Income(NT\$) & $>1,200,000$ & $3 \%$ \\
& $800,001-1,200,000$ & $3 \%$ \\
& $400,001-800,000$ & $32 \%$ \\
& $<400,000$ & $62 \%$ \\
\hline
\end{tabular}

\section{Measures}

Unless otherwise stated, all responses were made on a 6-point scale ranging from (1) strongly disagree to (6) strongly agree.

Perceived Organizational Support (POS) - Perceived organizational support was assessed using three items developed by Yoon and Thye (2000) (e.g., "My organization really cares about my well-being."). The internal consistency of this three-item scale was .91 in the current sample.

Leader-Member Exchange (LMX) - Leader-member exchange was measured using 12 items developed by Liden and Maslyn (1998) (e.g., "I do not mind 
working my hardest for my supervisor.”). The internal consistency of this 12item scale was .95 in the current sample.

Affective Commitment to Organization (ACO) - Affective commitment to the organization was measured using six items developed by Meyer, Allen and Smith (1993) (e.g., "I really feel that this organization's problems are my own."). The internal consistency of this six-item scale was 0.88 in the current sample.

Attitude towards New Information Systems (ATN) - Attitude towards New Information Systems was measured using three items adopted from Porter and Donthu (2006) (e.g., "I am positive toward the ERP systems". The internal consistency of this three-item scale was .89 in the current sample.

Overall, the strength of the internal consistency estimates of the variables in this study suggests homogeneity of the scale items.

\section{Analysis And Results}

\section{Analysis}

Before testing the study hypotheses, confirmatory factor analysis (CFA) was conducted with the AMOS software (Arbuckle, 2003) to examine the convergent and discriminant validity of the study measures. Given the large number of items (24) relative to the sample size (309), the procedures recommended by Mathieu and Farr (1991) were followed by creating six and three composite indicators for leader-member exchange and affective commitment to organization, respectively, in order to maintain an adequate sample-size-to-parameter ratio (Landis, Beal, \& Tesluk, 2000).

Following the approach suggested by Andersen and Gerbing (1988), convergent validity is demonstrated when the path loading $(\lambda)$ from an item to its latent construct is significant and exceeds 0.50. As shown in Table 2, all path loading $(\lambda)$ in this study was above 0.50 (0.79-0.95). In addition, convergent validity is also adequate when the constructs have an average variance extracted (AVE) of at least 0.50 and composite reliability (CR) greater than 0.6 (Hair, Anderson, Tatham, \& Black, 2006). As shown in Table 2 , the AVEs of all four constructs in this study exceed $0.50(0.68-0.77)$ and the CRs of all four constructs are also above 0.6 (0.88-.93). Thus, all constructs in this study demonstrate adequate convergent validity.

To assess discriminant validity, the procedures outlined by Fornell and Larcker (1981) were employed to examine whether the square root of AVE for the two constructs exceeds their correlation. As shown in Table 2, the square root of AVE for the two constructs is greater than their correlation. Thus, all tests of reliability and validity lead to the conclusion that the measures used in the subsequent statistical analyses are of acceptable reliability and validity. 
TABLE 2. Descriptive Statistics and Correlations Among Study Variables

\begin{tabular}{|c|c|c|c|c|c|c|c|c|c|}
\hline Variable & Mean & $\mathrm{SD}$ & $\begin{array}{c}\text { Cronbach } \\
\alpha\end{array}$ & $\overline{C R}$ & $\begin{array}{c}\text { Item } \\
\text { Loading }(\lambda) \\
(\min -\max )\end{array}$ & 1 & 2 & 3 & 4 \\
\hline 1. POS & 4.25 & 1.00 & .91 & .91 & $(.88-.89)$ & $(.88)$ & & & \\
\hline 2. LMX & 4.39 & .84 & .95 & .93 & $(.79-.85)$ & $.82 * *$ & $(.83)$ & & \\
\hline 3. ACO & 4.43 & .88 & .88 & .88 & $(.84-.85)$ & $.67 * *$ & $.69^{* *}$ & $(.85)$ & \\
\hline 4. ATN & 4.56 & .90 & .89 & .90 & $(.80-.95)$ & $.41 * *$ & $.41 * *$ & $.38 * *$ & $(.86)$ \\
\hline & & $\begin{array}{r}\text { AC } \\
\text { ATN }\end{array}$ & $\begin{array}{r}\text { POS }=\text { Perce } \\
\text { LMX }=\text { Le } \\
=\text { Affectiv } \\
\text { Attitudes to } \\
\text { CR= } \\
\text { Item Loa }\end{array}$ & $\begin{array}{l}\text { N } \\
\text { ed C } \\
\text { der-1 } \\
\text { Com } \\
\text { vard } \\
\text { impo } \\
\text { ing ( }\end{array}$ & $\begin{array}{l}\text { te: } \\
\text { ganization } \mathrm{S} \\
\text { ember-Exch } \\
\text { itment to Or } \\
\text { New Inform } \\
\text { ite reliability } \\
\text { is standardi }\end{array}$ & $\begin{array}{l}\text { port } \\
\text { ge } \\
\text { anizati } \\
\text { on Sys } \\
\text { d. }\end{array}$ & & & \\
\hline
\end{tabular}

Additionally, given that the data were collected from a single source, the procedures of Harman's one-factor test recommended by Podsakoff, Mackenzie, Lee and Podsakoff (2003) were conducted to examine whether the hypothesized four-factor model was superior to the one-factor model in order to rule out the influence of common-method bias. The result shows that the four-factor model $(\mathrm{GFI}=.92 ; \mathrm{CFI}=.97 ; \mathrm{TLI}=.96 ; \mathrm{RMSEA}=.069)$ had a better fit than the single-factor model $(\mathrm{GFI}=.69 ; \mathrm{CFI}=.75$; $\mathrm{TLI}=.71$; RMSEA = .18). Thus, although the present data may have common-method variance, the common-method bias does not seem to be a serious problem in this study.

\section{Hypothesis testing}

Means, standard deviations, internal reliabilities, and intercorrelations among the variables are reported in Table 2 . All measures show high internal reliabilities, with coefficient alphas ranging from .88 to .95 . In addition, perceived organizational support has a statistically significant positive relationship with the potential mediators, ACO $(0.67, \mathrm{p}<0.01)$ and with the outcome variable of attitude towards new IS $(0.41, \mathrm{p}<0.01)$. Moreover, LMX has a statistically significant positive relationship with ACO $(0.69, \mathrm{p}<0.01)$ and attitude towards new IS $(0.41, \mathrm{p}<0.01)$. In addition, ACO has a statistically significant positive relationship with attitude towards new IS $(0.38, \mathrm{p}<0.01)$. By and large, the pattern of correlations is consistent with the hypothesized directions.

Next, structural equation modeling was performed using AMOS 5.0 (Arbukle, 2003). According to Anderson and Gerbing's (1988) recommendation, the measurement model was tested before actually examining the hypothesized model. The full measurement model was tested 
whereby all latent variables in this study were allowed to correlate. The fit, according to $\mathrm{Hu}$ and Bentler (1999), was a good fit, with relative fit indices of 0.97 for CFI, 0.96 for TLI and 0.069 for RMSEA $\left(X^{2}=218.76\right.$. df $=84$, $\mathrm{CMIN} / \mathrm{DF}=2.604, \mathrm{p}<0.000)$. With the fitness of the measurement model confirmed, the hypothesized model was then tested.

The last step is to test the mediating roles of ACO in the relation between POS and attitude towards new IS, and between LMX and Attitude towards New IS. Bootstrapping was employed to test directly for the mediators with the AMOS software since bootstrapping is currently regarded as a more powerful tool for testing the mediating effects in comparison with Baron and Kenny's (1986) approach (Preacher \& Hayes, 2008).

As a result, the standard estimated indirect effect of POS on attitude towards new IS (95\% CI: $0.078-0.315)$, and the standard estimated indirect effect of LMX on attitude towards new IS was 0.17 (95\% CI: 0.062-0.318). These results confirm the mediating roles of ACO in the hypothesized relations.

Further, in order to test whether a full mediating relationship exists between POS and attitude towards new IS, a competitive modeling test was conducted. Table 3 presents fit indices for the hypothesized model, along with three alternative models. Results of comparison show that the three alternative models do not indicate a significant improvement in model fit when compared with the hypothesized model. Thus, the hypothesized model is the most adequate for explaining the data as indicated by a RMSEA of 0.071, a CFI of 0.964 , a GFI of 0.915 , and a TLI of 0.956 .

TABLE 3. Competitive Model Test

\begin{tabular}{ccccccccc}
\hline & $\mathrm{X}^{2}$ & $\mathrm{df}$ & $\mathrm{X}^{2} / \mathrm{df}$ & $\Delta \mathrm{X}^{2}$ & RMSEA & CFI & TLI & GFI \\
\hline Hypothesized & 230.17 & 86 & 2.676 & & .071 & .96 & .96 & .92 \\
$\begin{array}{c}\text { Model } \\
\text { Alternative }\end{array}$ & 218.95 & 85 & 2.576 & 11.22 & .069 & .97 & .96 & .92 \\
$\begin{array}{c}\text { Model 1 } \\
\text { Alternative } \\
\begin{array}{c}\text { Model 2 } \\
\text { Alternative }\end{array}\end{array}$ & 224.97 & 85 & 2.647 & 5.20 & .070 & .97 & .96 & .92 \\
$\begin{array}{c}\text { Model 3 } \\
\text { c }\end{array}$ & 218.76 & 84 & 2.604 & 11.41 & .069 & .96 & .96 & .92 \\
\hline
\end{tabular}

${ }^{\text {a }}$ Alternative Model 1 only added the direct path from POS to attitude toward new information system.

${ }^{\mathrm{b}}$ Alternative Model 2 only added the direct path from LMX to attitude toward new information system.

${ }^{c}$ Alternative Model 3 added (1) the direct path from POS to attitude toward new information system (2) the direct path from LMX to attitude toward new information system.

Standardized parameter estimates for the hypothesized model are shown in Figure 1. For ease of presentation, only the structural model is 
presented rather than the full measurement model. Examining the path coefficients reveals that both POS and LMX are uniquely related to ACO in the positive direction; ACO has significant direct association with attitude towards new IS. Thus, Hypotheses 1, 2, 3 and 4 are all supported.

Figure 1 depicts the final results from test of hypothesized Model.

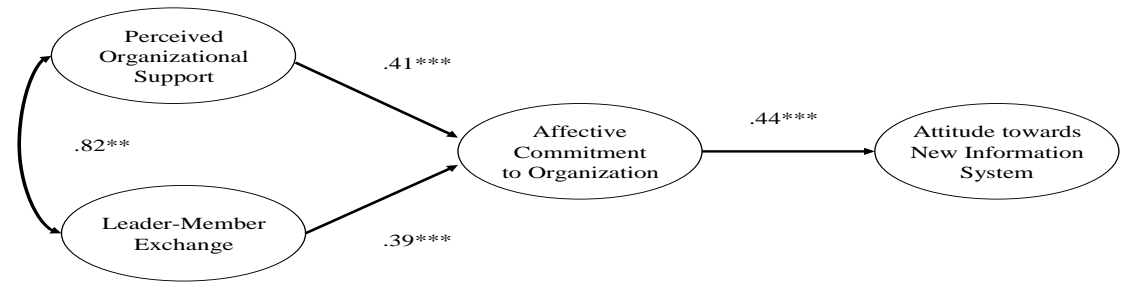

Figure 1. Results from test of hypothesized Model

\section{Discussion and conclusion Summary of Findings}

In essence, the present findings are consistent with Graham's (1991) contention that employee's attitudes and behavioral intent are primarily driven by employees' perceptions of being valued and cared by the organization and his/her supervisor. Specifically, given that organizational participants typically engage in multiple exchange relationships, findings of this study reveal that both POS and high-quality LMX can function as means of enhancing ACO which, in turn, motivates employees' positive attitude towards new IS.

Furthermore, the present findings are also consistent with previous factor analysis results indicated that POS and LMX load on separate factors (Kottke and Sharafinski, 1988); are distinct constructs (Masterson, Lewis, Goldman and Taylor, 2000; Settoon, Bennet and Liden, 1996; Wayne et al., 1997), and are empirically related (Wayne, et al., 1997). Specifically, with respect to high correlation, according to the concept of personification of organization (Levinson, 1965), the immediate supervisor's behaviors are likely to be perceived by employees as representative of organizational decisions (Griffin, Patterson, \& West, 2001), and high-quality LMX relationships is likely interpreted as the organization's benevolent or malevolent orientation towards them. In that event, a high correlation between POS and LMX, as results shown, is predictable. 
By and large, these results point to the efficacy of POS and LMX in fostering employees' positive attitudes towards new IS. Specifically, this study reveals implicitly that both a supportive organization and a high-quality relationship between supervisor-supervisee and employees are likely to strengthen employees' felt obligation which, in turn, enhances their ACO and attitude towards new IS. In sum, this finding supports the dynamics of social exchange theory in influencing employee's attitude towards new IS.

\section{Practical Implications}

The results of the current investigation have practical implications for organizations when adopting new IS. First, the findings of this study suggest that success in adopting new IS depends on, at least in part, POS. Realizing the importance of organizational support in successful adoption of new IS, organizations should consider how they might create emplooyees' perception of organizational support within their organizations.

In essence, POS would be influenced by various aspects of employees' treatment by the organization and their interpretation of organizational motives underlying that treatment (Eisenberger et al., 1986). Specifically, as Shore and Shore (1995) identified, two key types of human resource practices are related to perceived organizational support: (1) discretionary practices that imply investment by the organization in an employee (e.g., time off for training/education) and (2) performance recognition (e.g., performance bonus/incentives).

Further, since individuals view these practices as indicating positive evaluations of themselves by the organization (Wayne et al., 1997), HRM practitioners should thus devote efforts to establishing a fair, supportive and satisfying working environment by designing and implementing HRM practices, such as "employee assistance program" (EAP), "performance appraisal system" and "employee grievance system", in order to enhance employees' perception of organizational support.

In addition, with respect to LMX, as Neves and Eisenberger (2012) suggested, effective management communication should signal that the organization cares about the well-being and values the contributions of its employees. Hence, HRM practitioners should focus on management development training programs (e.g., communication skills) with the ultimate goal of facilitating employees' intent to use new IS.

Second, the results of this study confirm that ACO also account for variance in employees' attitude towards new IS as well as POS. In other words, organizations, when adopting new IS, should also pay particular attention to enhancing their employees' ACO. Specifically, previous studies have confirmed the positive relationship of $\mathrm{ACO}$ with organizational justice (Judge and Colquitt, 2004; Loi et al., 2006; Meyer et al., 2002) and job satisfaction 
(Stinglhamber and Vandenberghe, 2003; Yousef, 2000). In that case, management and HRM practitioners should devote efforts to enhance organizational justice and job satisfaction in order to nurture employees' affective commitment to organization which, according to the findings of this study, can foster their intent to use new IS.

\section{Limitations \& Directions for Future Research}

Like previous research, this study also has certain limitations. First, the sample is confined to a limited number of companies, three in Hsinchu County with 309 respondents, which might in turn limit the generalizability of its findings and conclusions to other enterprises. Second, this approach introduces potential problems of common-method bias as the research variables were gathered from the same source, although a Harmon singlefactor test (Podsakoff et al., 2003) shows that common-method bias is not a serious problem in this study. Third, one must be cautious when interpreting the findings of this study due to the possible constraint of non-response bias, such that non-respondents might hold different views with respect to the variables in question, leading to possible bias in survey estimates. Finally, this study suffers from the common limitations of cross-sectional field research. Hence, caution is necessary for its inability to make causal inferences with confidence between the variables examined in the study.

Regarding the directions for future research, as noted by Podsakoff et al. (2003), using self-reported measures for studied constructs may inflate their correlations due to self-reporting bias. Thus, future research should focus on other ratings of attitude towards new Information system to reduce commonmethod variance. For instance, the use of immediate supervisors or coworkers' assessments of intent to use new information systems would further validate the use of individuals' self-reported perceived organizational support, leadermember exchange and affective commitment measures.

Furthermore, results of the current study suggest that when LMX and POS are examined within the same study, LMX dominates POS in explaining variance in ACO, which is contrary to the findings of Settoon, et al. (1996). A possible explanation for such discrepancy is that since Chinese culture fosters a strong vertical linkage between supervisor and subordinates (Redding, 1990), LMX is more important in the Chinese context than in the Western context (Cheng, Jiang and Riley, 2003). In view of this, future research should conduct cross-cultural investigation in order to understand whether cultural context leads to difference in explaining the variance.

\section{Conclusion}

In spite of the aforementioned limitations, this study has a couple of unique contributions. First, it sheds new light on understanding the key 
determinants of employee's attitude towards new IS from the perspective of the social fabric of organization (social exchange relationship in this case). Such understanding can assist in the proactive planning of intervention mechanisms for maximizing the possibility of success in adopting new IS.

More specifically, given that perceived ease of use, perceived usefulness, system quality, information system, service quality, user satisfaction, system satisfaction and information satisfaction have confirmed their influences on initial user acceptance and sustained usage of new systems (Chen, et al., 2013; Davis et al., 1989; DeLone and McLean, 1992,2003; Wixom \& Todd, 2005;)., this study provides an alternative approach to understanding the driving force behind attitude towards new IS which determines employees' acceptance and use of new IS.

Second, as noted by Judge and Kammeyer-Mueller (2012), it is only in recent years that researchers have systematically demonstrated that social environment variables, such as relationships with supervisors, can be as closely related to overall job attitudes. In consistence with previous results which reinforce the notion that attitudes toward work are significantly related to the social relationships one has (Judge and Kammeyer-Mueller, 2012), results of this study provide the proof of the importance of social exchange relationship (i.e., POS and LMX) in influencing employee's attitude towards new IS during the process of adoption. In this regard, it explores a path for researchers to investigate the importance of social environment variables for successful adoption of new IS.

Third, the results of this study confirm that ACO, as a mediator, also account for variance in employees' attitude towards new IS. Previous studies have indicated the positive relationship of ACO with employee's perceptions and attitudes, findings of this study confirm the mediating role of ACO whilst adopting new IS. It provides management and HRM practitioners with convincing evidence to enhance employee's ACO for successful adoption of new IS.

\section{References:}

Allen, J., Jimmieson, N. L., Bordia, P., \& Irmer, B. (2007). Uncertainty during Organizational Change: Managing Perceptions through Communication. Journal of change management, 7(2), 187-210.

Allen, N. J., \& Meyer, J. P. (1990). The measurement and antecedents of affective, continuance and normative commitment to the organization. Journal of Organizational Psychology, 63(1), 1-18.

Anderson, J. C., \& Gerbing, D. W. (1988). Structural equation modeling in practice: A review and recommended two-step approach. Psychological Bulletin, 103(3), 411-423. 
Arefin, M.S. \& Raquib, M. (2015). The Relationship between High Performance Work Systems and Proactive Behaviors: The Mediating Role of Perceived Organizational Support. European Scientific Journal, 11(2), 314327.

Aselage, J., \& Eisenberger, R. (2003). Perceived organizational support and psychological contract: a theoretical integration. Journal of Organizational Behavior, 24(5), 491-509.

Avgerou, C. (2001). The significance of context in information systems and organizational change. Information Systems Journal, 11(1), 43-63.

Aselage, J. \& Eisenberger, R. (2003). Perceived organizational support and psychological contract: a theoretical integration. Journal of Organizational Behavior, 24(5), 491-509.

Avgerou, C. (2001). The significance of context in information systems and organizational change. Information Systems Journal, 11(1), 43-63.

Baron, R. M. \& Kenny, D. A. (1986). The moderator-mediator variable distinction in social psychological research: Conceptual, strategic, and statistical considerations. Journal of Personality and Social Psychology, 51(6), 1173-1182.

Blau, P.M. (1964). Exchange and power in social life. New York, NY: John Wiley.

Bouarif, N. (2015). Predicting Organizational Commitmnt: The Role of Religiosity and Ethical Ideology. European Scientific Journal, 11(17), 283307.

Chen, J.V., Rungruengsamrit, D., Rajkumar, T.M., \& Yen, D.C. (2013). Success of Electronic Commerce Web Sites: A Comparative Study in Two Countries. Information \& Management, 50(6), 344-355.

Cheng, B. S., Jiang, D. Y., \& Riley, J. H. (2003). Organizational commitment, supervisory commitment, and employee outcomes in the Chinese context: proximal hypothesis or global hypothesis?. Journal of Organizational Behavior, 24(3), 313-334.

Cropanzano, R. \& Mitchell, M. (2005). Social exchange theory: An interdisciplinary review. Journal of Management, 31 (6), 874-900.

Dansereau, F., Graen, G. B., \& Haga, W. J. (1975). A vertical syad approach to leadership within formal organizations. Organizational Behavior and Human Performance, 13, 46-78.

Davis, F., Bagozzi, R., \& Warshaw, P. (1989). User Acceptance of Computer Technology: A Comparison of Two Theoretical Models. Management Science, 35(8), 982-1003.

Delone, W.H., \& McLean, E.R. (1992). Information Systems Success: The Quest for the Dependent Variable. Information Systems Research, 3(1), 60-95. 
Delone, W. H., \& McLean, E.R. (2003). The DeLone and McLean Model of Information Systems Success: A Ten-Year Update. Journal of Management Information System, 19(4), 9-30.

Dirks, K. T., \& Ferrin, D. L. (2001). The Role of Trust in Organizational Settings. Organization Science, 12(4), 450-467.

Dvir, T., Kass, N., \& Shamir, B. (2004). The emotional bond: vision and organizational commitment among high-tech employees. Journal of Organizational Change management, 17(2), 126-143.

Dyne, L.V., Graham, J.W. \& Dienesch, R.M. 1994, "Organizational citizenship behavior: construct redefinition, measurement, and validation". Academy of Management Journal, 37(4): 765-802.

Eisenberger, R., Armeli, S., Rexwinkel, B., Lynch, P. D. \& Rhoades, L. (2001). Reciprocation of perceived organizational support. Journal of Applied Psychology, 86 (1), 42-51.

Eisenberger, R., Fasolo, P., \& David-LaMastro, V. (1990). Percived organizational support and employee deligence, commitment,and innovation. Journal of Applied Psychology, 75(1), 51-59.

Eisenberger, R., Huntington, R., Hutchison, S. \& Sowa, D. (1986). Perceived organizational support. Journal of Applied Psychology, 71(3), 975-991.

Eisenberger, R., Karagonlar, G., Stinglhamber, F., Neves, P., Becker, T. E., Gonzalez-Morales, M. G., \& Steiger-Mueller, M. (2010). Leader-member exchange and Affective Organizational commitment: The Contribution of Supervisor's Organizational Embodiment. Journal of Applied Psychology, 95(6), 1085-1103.

Erdogan, B., Liden, R.C., and Kraimer, M.L. (2006). Justice and leadermember exchange: the moderating role of organizational culture. Academy of Management, 49(2), 395-406.

Fedor, D. B., Caldwell, S. \& Herold, D. M. (2006). The effects of organizational changes on employee commitment: A multilevel investigation. Personnel Psychology, 59(1), 1-19.

Fornell, C. R. \& Larcker, D. F. (1981). Structural equation models with unobservable variables and measurement error. Journal of Marketing Research, 18(3), 39-50.

Gerstner, C. R., \& Day,D.V. (1997). Meta-analytic review of leader-member exchange theory:

Correlates and construct issues. Journal of Applied Psychology, 82, 827-844.

Glisson, C. \& Durick, M. (1988). Predictors of Job Satisfaction and Organizational Commitment". Administrative Science Quarterly, 33(1), 6181.

Gouldner, A. W. (1960). The norm of reciprocity: A preliminary statement. American Sociological Review, 25(2), 161-178. 
Graen, G. B., \& Scandura, T. A. (1987). Toward a psychology of dyadic organizing. In L. L. Cummings \& B. M. Staw (Eds.), Research in organizational behavior(pp. 175-208). Greenwich, CT: JAI Press.

Graham, J. W. (1991). An essay on organizational citizenship behavior. Employee Respond Rights Journal, 4(4), 249-270.

Griffin, M. A., Patterson, M. G., \&West, M. A. (2001). Job satisfaction and teamwork: The role of supervisor support. Journal of Organizational Behavior, 22, 537-550.

Hair, J. J. F., Anderson, R., Tatham, R. L. \& Black, W. C. (2006) Multivariate Data Analysis -International Editions(6th ed.). Englewood Cliffs, NJ: Prentice Hall.

Hammer, M., \& Champy, J. (1993). Reengineering the Corporation, A manifesto for Business Revolution. London; Nicholas Brealey.

Hornstein, H.A. (2015). The integration of project management and organizational change management is now a necessity. International Journal of Project Management, 33(2), 291-298.

Hu, L., \& Bentler, P.M. (1999). Cutoff criteria for fit indices in coveriance structure analysis: conventional criteria versus new alternatives. Structural Equation Modelling, 6(1), 1-55.

Ilies, R., Nahrgang, J. D., \& Morgeson, F. P. (2007). Leader-Member Exchange and Citizenship Behaviors: A Meta-Analysis. Journal of Applied Psychology, 92(1), 269-277.

Iverson, R. D. (1996). Employee acceptance of organizational change: the role of organizational commitment. The international Journal of Human Resource Management, 7(1), 122-149.

Jacobson, S., Shepherd, J., D'Aquila, M., \& Carter, K. (2007). The ERP market sizing report 2006 - 2011. AMR Research. http://www.sap.com/uk/solutions/businesssuite/erp/pdf/AMR_ERP_Market_Sizing_2006-2011.

pdf. Accessed November 25, 2010.

Jaskyte, K. (2003). Assessing changes in employees' perceptions of leadership behavior, job design, and organizational arrangements and their job satisfaction and commitment. Administration in Social Work, 27(4), 25-39. Judge, T. A., \& Colquitt, J. A. (2004). Organizational Justice and Stress: The Mediating Role of Work-Family Conflict. Journal of Applied Psychology, 89(3), 395-404.

Judge, T.A. \& Kammeyer-Mueller,J.D., (2012). Job Attitudes. Annal Review of Psychology. 63, 341-367.

Klein, H. J., \& Kim, J. S. (1998). A Field Study of the Influence of Situational Constraints Leader-Member Exchange, and Goal Commitment on Performance. Academy of Management Journal, 41(1), 88-95. 
Kottke,J.L., \& Sharafinski, C. E. (1988). Measuring Perceived Supervisory and Organizational Support. Psychological Measurement, 48(4), 1075-1079. Landis, R. S., Beal, D. J. \& Tesluk, P. E. (2000). A comparison of approaches to forming composite measures in structural equation models. Organizational Research Methods, 3(2), 186-207.

Lapierre, L. M., \& Hackett, R. D. (2007). Trait conscientiousness, leadermember exchange, job satisfaction and organizational citizenship behaviour: A test of an integrative model. Journal of Occupational and Organizational Psychology, 80(3), 539-554.

Levinson, H. (1965). Reciprocation: The relationship between man and organization. Administrative Science Quarterly, 9(4), 370-390.

Liden, R. C., \& Maslyn, J. M. (1998). Multidimensionality of leader-member exchange: An empirical assessment through scale development. Journal of Management, 24(1), 43-72.

Lind, E. A., Tyler, T. R., \& Huo, Y. J. (1997). Procedural Context and Culture: Variation in the Antecedents of Procedural Justice Judgments. Journal of Personality and Social Psychology, 73(4), 767-780.

Loi, R., Hang-Yue, N., \& Foley, S. (2006). Linking employees' justice perceptions to organizational commitment and intention to leave : The mediating role of perceived organizational support. Journal of Occupational and Organizational Psychology, 79(1), 101-120.

Malatesta, R. M. (1995). Understanding the dynamics of organizational and supervisory commitment using a social exchange framework. Unpublished doctoral dissertation, Wayne State University, Detroit, MI.

Masterson, S. S., Lewis, K., Goldman, B. M., \& Taylor, M. S. (2000). Integrating justice and social exchange: The differing effects of fair procedures and treatment on work relationships. Academy of Management Journal, 43(4), 738-748.

Mathieu, J. E. \& Farr, J. L. (1991). Further evidence for the discriminant validity of measures of organizational commitment, job involvement, and job satisfaction. Journal of Applied Psychology, 76(1), 127-133.

Meyer, J. P., \& Allen, N. J. (1991). A Three-component conceptualization of orgnaizational commitment. Human Resource Management Review, 1(1), 6189.

Meyer, J. P., \& Allen, N. J. (1997). Commitment in the workplace: Theory, research, and application. CA: Sage publications.

Meyer, J. P., Allen, N. J., \& Smith, C. A. (1993). Commitment to organizations and occupations: Extension and test of a three-component conception. Journal of Applied Psychology, 78(4), 538-552.

Meyer, J. P. \& Herscovitch, L. (2001). Commitment in the workplace toward a general model. Human Resource Management Review, 11(3), 299-326. 
Meyer, J. P., Srinivas, E. S., Lai, J. B. \& Topolnytsky, L. (2007). Employee commitment and support for an organizational change: test of the threecomponent model in tow culture. Journal of Occupational and Organizational Psychology, 80(2), 185-211.

Meyer, J. P., Stanley, D. J., Herscovitch, L., \& Topolnytsky, L. (2002). Affective, continuance, and normative commitment to the organization. Journal of Vocational Behavior, 61(1), 20-52.

Miller, V. D., Johnson, J. R. \& Grau, J. (1994). Antecedents to willingness to participate in a planned organizational change. Journal of Applied Communication Research, 22(1), 59-80.

Mulwa,A.S. \& kyalo, D.N. (2013). The Influence of Principals', Teachers' and Students' Attitude on Readness to Adopt e-Learning in Secondary Schools in Kitui District, Kenya. European Scientific Journal, 9(5), 183-202.

Neves, P., \& Eisenberger, R. (2012). Management Communication and Employee Performance: The Contribution of Perceived Organizational Support. Human Performance, 25(5), 452-464.

Momoh, A., Roy, R., \& Shehab, E. (2010). Challenges in enterprise resource planning implementation: state-of-the-art. Business Process Management, 16(4), 537-565.

Organ, D. W. (1990). The Motivational basis of Organizational Citizenship Behavior. In B. M. Staw \& L. L. Cummings (Eds.), Research in Organizational Behavior (Vol. 12, pp. 43-72). Greenwich, CT: JAI Press.

Organ, D.W., \& Konovsky, M. (1989). Cognitive Versus Affective Determinants of Organizational Citizenship Behavior. Journal of Applied Psychology, 74,(1), 157-164.

Podsakoff, P. M., MacKenzie, S. B., Lee, J. Y. \& Podsakoff, N. P. (2003). Common method biases in behavioral research: A critical review of the literature and recommended remedies. Journal of Applied Psychology, 88(5), 879-903.

Porter, C. E., \& Donthu, N. (2006). Using the technology acceptance model to explain how attitudes determine Internet usage: The role of perceived access barriers and demographics. Journal of Business Research, 59, 999-1007.

Preacher, K. J., \& Hayes, A. F. (2008). Asymptotic and resampling strategies for assessing and comparing indirect effects in multiple mediator models. Behavior Research Methods, 40(3), 879-891.

Redding, S. G. (1990). The spirit of Chinese capitalism. Berlin: Walter de Gruyter.

Rhoades, L., \& Eisenberger, R. (2002). Perceived organizational support: A review of the literature. . Journal of Applied Psychology,, 87(4), 698-714.

Rhoades, L., Eisenberge, R., \& Armeli, S. (2001). Affective Commitment to the Organization : The Contribution of Perceived Organizational Support. Journal of Applied Psychology, 86(5), 825-836. 
Schriesheim, C. A., Castro, S. L., Zhou, X., \& Yammarino, F. J. (2001). The folly of theorizing " $A$ " but testing "B": A selective level of analysis review of the field and a detailed leader-member exchange (LMX) illustration. The Leadership Quarterly, 12(4), 515-551.

Settoon, R. P., Bennett, N., \& Liden, R. C. (1996). Social Exchange in Organizations: Perceived Organizational Support, Leader-Member Exchange, and employee Reciprocity. Journal of Applied Psychology, 81(3), 219-227.

Shore, L.M. \& Shore, T.H. (1995). Perceived organizational support and organizational justice. In Cropanzano, R.S. \& K.M. Kacmar (Eds.). Organizational politics, justice, and support: Managing the social climate of the workplace (pp.149-164), Westport, CT: Quorum.

Stinglhamber, F., \& Vandenberghe, C. (2003). Organizations and supervisors as sources of support and targets of commitment: a longitudinal study. Journal of Organizational Behavior, 24(3), 251-270.

Vakola, M. \& Nikolaou, I. (2005). Attitudes towards organizational change: What is the role of employees' stress and commitment?. Employee Relations, 27(2), 160-174.

Venkatesh, V. (2000). Determinants of Perceived Ease of Use: Integrating control, Intrinsic Motivation, and Emotion into the Technology Acceptance Model. Information Systems Research, 11(4), 342-365.

Wayne, S. J., Shore, L. M. \& Liden, R. C. (1997). Perceived organizational support and leader-member exchange: A social exchange perspective. Academy of Management Journal, 40(1), 82-111.

Wayne, S. J., Shore, L.M., Bommer, W.H., \& Tetrick, L.E. (2002). The Role of Fair Treatment and Rewards in Perceptions of Organizational Support and Leader-Member Exchange. Journal of Applied Psychology, 87(3), 590-598.

Witt, L. A., Kacmar, K.M., \& Andrews, M. C. (2001). The interactive effects of procedural justice and exchange ideology on supervisor-rated commitment. Journal of Organizational Behavior 2001, 22(5), 505-515.

Wixom, B. H., \& Todd, P. (2005). A Theoretical Integration of User Satisfaction and Technology Acceptance. Information Systems Research, 16(1), 85-102.

Yoon, J., \& Thye, S. (2000). Supervisor support in the work place: Legitimacy and Positive affectivity. The Journal of Social Psychology, 140(3), 295-316.

Yousef, D. A. (2000). Organizational commitment and job satisfaction as predictors of attitudes toward organizational change in a non-western setting. Personnel review, 29(5), 567-592.

Zeinabadi, H., \& Rastegarpour, H. (2010). Factors affecting teacher trust in principal: testing the effect of transformational leadership and procedural justice. Procedia Social and Behavioral Sciences, 5, 1004-1008. 